\title{
Desiccation, postharvest maturity and seed aging of tall oat-grass
}

\author{
Rade Stanisavljević(1), Dragoslav Djokić(1), Jasmina Milenković(1), Dragan Terzić(1), Lana Djukanović(2), \\ Vladeta Stevović(3), Dejan Dodig ${ }^{(4)}$
}

\begin{abstract}
(1)Institute of Forage Crops, Trg Kosturnice 50, 37000 Kruševac, Serbia. E-mail: rade.stanisavljevic@ikbks.com, dragoslav.djokic@ikbks.com, jasmina.milenkovic@ikbks.com, dragan.terzic@ikbks.com ${ }^{(2)}$ Sirmium-seme Laboratory for Seed Testing, Kralja Petra I 5-7, 22000

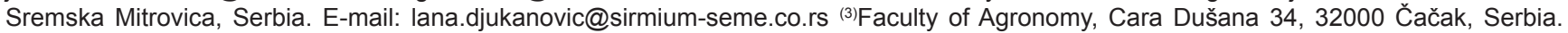
E-mail: vladeta@tfc.kg.ac.rs ${ }^{(4)}$ Maize Research Institute, Zemun Polje, Slobodana Bajića 1, 11185 Belgrade-Zemun, Serbia. E-mail: ddodig@mrizp.rs
\end{abstract}

\begin{abstract}
The objectives of this work were to determine whether and at which seed physiological maturity stage the diquat desiccant affects the tall oat-grass (Arrhenatherum elatius) seed quality and yield, as well as the proper storage period between harvest and sowing. Diquat desiccation was evaluated in applications during milk or dough seed maturation stages. Seeds conventionally produced and stored under traditional storage conditions were used for the analyses. Seed samples were drawn every $30^{\text {th }}$ day after harvest (DAH). After the $240^{\text {th }} \mathrm{DAH}$, samples were drawn every $90^{\text {th }}$ day up the to $690^{\text {th }} \mathrm{DAH}$. The highest yield were obtained by desiccation applied at the beginning of the seed dough stage, with a satisfactory seed quality. Both final germination and seedling growth parameters achieved their maximum values between $180^{\text {th }}$ and $240^{\text {th }} \mathrm{DAH}$. Oat-grass seeds preserved satisfactory level of final germination (75\%) up to $420^{\text {th }} \mathrm{DAH}$. The application of diquat desiccant at the beginning of seed dough maturity stage can be a good solution for seed production of tall oat-grass. Early spring is the best sowing period for freshly harvested seeds of tall oat-grass regarding germination and seedling growth.
\end{abstract}

Index terms: Arrhenatherum elatius, germination, seed dormancy.

\section{Dessecação, maturidade pós-colheita e deterioração de sementes de aveia-perene}

\begin{abstract}
Resumo - O objetivo deste trabalho foi determinar se e em qual estágio de maturidade fisiológica das sementes o dessecante diquat afeta a produtividade e a qualidade de sementes de aveia-perene (Arrhenatherum elatius), bem como o período de armazenamento adequado entre colheita e semeadura. O dessecante diquat foi avaliado em aplicações nos estágios de leite ou de cera do amadurecimento de sementes. Sementes produzidas convencionalmente e armazenadas em condições tradicionais foram utilizadas para as análises. Amostras de sementes foram coletadas a cada 30 dias após a colheita (DAC). Após o $240^{\circ}$ DAC, as amostras foram retiradas a cada 90 dias até o $690^{\circ}$ DAC. A maior produtividade, com qualidade satisfatória da semente, foi obtida pela dessecação aplicada no início da fase de cera. A germinação final e os parâmetros de crescimento das plântulas alcançaram valores máximos entre 180 e 240 dias após a colheita. As sementes de aveia-perene mantiveram germinação final satisfatória $(75 \%)$ até 420 dias após a colheita. A dessecação com diquat, na fase inicial do estágio de cera do amadurecimento das sementes, pode ser uma boa solução para a produção de sementes de aveia perene. $\mathrm{O}$ início da primavera é o melhor período para plantio de sementes recém-colhidas de aveia-perene, em termos de germinação e crescimento de plântulas.
\end{abstract}

Termos para indexação: Arrhenatherum elatius, germinação, dormência de sementes.

\section{Introduction}

Due to the intensive agricultural production, semi-natural Arrhenatherum elatius meadows are becoming scarce in Central Europe, in spite of the ever growing significance of their biodiversity value. Thereby, the tall oat-grass seed production is of a great importance for the increase of areas under this species (Scotton et al., 2009). In Southeastern Europe, where agriculture is less intensive, tall oat-grass is an important species that provide components for feedstuff from both natural and sown lawns. For instance, the distribution of tall oat-grass in natural meadow in the region of Stara Planina (Eastern Serbia), up to $700 \mathrm{~m}$ above sea, amounts to $16.7 \%$ (Tomić et al., 2009). The dry matter yield of cultivated tall oat-grass monocrop amounts to 8.7, 9.8 and 8.1 $\mathrm{Mg} \mathrm{ha}^{-1}$ in Eastern, Central and Northern Serbia, respectively (Tomić et al., 
2007). A great morphological variability within tall oat-grass populations provides a great adaptability to environmental conditions and a wide distribution (Sokolović et al., 2004).

Desiccation is applied in seed production to reduce water contents in plant and seed in order to provide a more even and rapid maturation, and to reduce seed shedding, which result in higher yields, and in economic drying and storage of seeds. Seed shedding is one of the major problems in seed production of fodder grasses, especially of tall oat-grass (Miladinović, 2001). Diquat is a registered non-selective contact desiccant which acts quickly to damage cell membranes (Mitić, 2000). It showed good results in desiccation of alfalfa (Moyer et al., 1996) and bird's-foot trefoil (Petrović et al., 1996). However, to our best knowledge there are no data of this herbicide application and effects on the yield and seed quality of tall oat-grass.

Although there are many studies on seed dormancy during the post-harvest maturation period, little is known about the processes that detain germination during this period (Bewley, 1997). Agricultural species, as vegetable crops, normally have short seed dormancy because seeds are adjusted by breeding to fast and uniform germination. The sowing period for agricultural species is often adapted to the highest seed germination. However, seed dormancy is very pronounced in the majority of fodder grasses. Under natural conditions, seed dormancy after seed shedding significantly affects changes in plant communities and in the grass cover (Adkins et al., 2002).

After the maturation period, peroxidation of polyunsaturated fatty acids damages cell membranes and DNA, and leads to seed aging and germination reduction (Simpson, 1990).

The objectives of this work were to determine whether and at which seed physiological maturity stage diquat desiccant affects the tall oat-grass (Arrhenatherum elatius) seed quality and yield, and the proper storage period between harvest and sowing.

\section{Materials and Methods}

The study on the effects of desiccation on tall oat-grass, Arrhenatherum elatius (L.) P. Beauv. Ex J. Pres1 \& C. Presl., seed yield and quality was performed in the experimental field of the Institute of Forage Crops (Central Serbia $43^{\circ} 34^{\prime} \mathrm{N}, 21^{\circ} 19^{\prime} \mathrm{E}, 232 \mathrm{~m}$ altitude), during the second (2007), third (2008) and the fourth (2009) cultivation years. The four-replicate trial was set up according to a randomized complete block design. The elementary plot size had $12 \mathrm{~m}^{2}(4 \times 3 \mathrm{~m})$. The variety $\mathrm{K}-12$, developed in Serbia, was used in the study.

The desiccation effect of the non-selective contact herbicide diquat (at the concentration of $3.5 \mathrm{~L} \mathrm{ha}^{-1}$ ) on yield, shedding and quality of tall oat-grass seeds was evaluated in two seed physiological maturity stages (milk and dough stages) in pre-harvest, in comparison to the control without desiccation. In the first treatment, desiccation was carried out when $70 \%$ of seeds were in the milk stage, $20 \%$ at the beginning of the dough stage, and $10 \%$ at the end of dough stage (i.e. at the harvest maturation stage); in the second one, desiccation was carried out when $70 \%$ of seeds were at the beginning of the dough stage, $20 \%$ at the harvest maturity, and $10 \%$ in the milk stage. Seeds in the control treatment were harvested when $70 \%$ of seeds were at the harvest maturity, $20 \%$ at the beginning of dough stage, and $10 \%$ in the milk stage.

Harvested seeds were dried down to $13 \%$ moisture content in all treatments. Seed shedding was estimated by weight measuring of seeds shed in relation to the total yield, expressed in percentage. Seed quality was determined on the base of 1,000-seed weight, expressed in grams. For germination, 4x100 seeds from each replicate were tested on filter paper (TP) according to the ISTA rules (International Seed Testing Association, 2008). After a pre-chill treatment at $5^{\circ} \mathrm{C}$ for 5 days, seeds germinated at alternating temperatures of $30 / 20^{\circ} \mathrm{C}\left(30^{\circ} \mathrm{C}\right.$ for 8 hours of light and $20^{\circ} \mathrm{C}$ for 16 hours of dark). The final count of normal seedlings was made after 14 days.

Tall oat-grass seeds harvested in 2007 were conventionally produced, and employed for germination tests according to post-harvest maturation and aging. Collected seeds were cleaned manually, placed in plastic bags and stored dry (13\%) under standard warehouse conditions. Temperature and air moisture regimes during three years in the standard warehouse are presented in Table 1. Samples for laboratory analyses were drawn during the post-harvest maturation every 30 day after harvest (DAH). When the post-harvest maturation was finished off and when germination reached its maximum (240 DAH), samples were drawn every 90 day, during the second and third year of investigation, up to the $690 \mathrm{DAH}$. Germination 
was tested according to the ISTA rules, as described above. Besides normal and abnormal seedlings, the percentage of dead and dormant seeds were estimated. The primary root length $(\mathrm{cm})$, shoot length $(\mathrm{cm})$ and fresh seedling biomass (root + shoot, $\mathrm{mg}$ ) were also measured after the final count for normal seedlings. The seedling length was measured using a ruler.

Data were subjected to analyses of variance, in a factorial arrangement with two factors (desiccation period and year) for grain yield and final germination in the desiccation test, and one factor (after harvest period) for final germination and seedling quality parameters in the post-harvest maturity and seed aging test. Treatment means were compared by the least-significant difference (LSD) test at 5\% probability. To correct for non-normality, the germination and seed shedding percentage values were transformed using arcsine. Relationship between germination, seed yield and 1,000-seed weight were estimated by Pearson correlation analysis.

\section{Results and Discussion}

The same cropping practices were applied throughout the experiment, and the agroecological conditions were fairly the same. The yield obtained with the desiccation in the dough stage was significantly higher than when it was performed in the milk stage or when it was not done (Table 2). Although the yield obtained with desiccation in the milk stage during the first two years was not significantly higher from the control, on the average of the three years, the difference between these two

Table 1. Maximum and minimum temperature and relative air humidity values in seed storage rooms.

\begin{tabular}{|c|c|c|c|c|c|c|}
\hline \multirow[t]{2}{*}{ Month $^{(1)}$} & \multicolumn{3}{|c|}{ Temperature $\left({ }^{\circ} \mathrm{C}\right)$} & \multicolumn{3}{|c|}{ Relative air humidity (\%) } \\
\hline & Average & Minimum & Maximum & Average & Minimum & Maximum \\
\hline January & 2 & 1 & 3 & 81 & 75 & 86 \\
\hline February & 6 & 3 & 9 & 79 & 70 & 87 \\
\hline March & 9 & 4 & 13 & 78 & 68 & 87 \\
\hline April & 11 & 6 & 15 & 66 & 49 & 83 \\
\hline May & 13 & 7 & 18 & 65 & 47 & 82 \\
\hline June & 20 & 15 & 24 & 63 & 45 & 80 \\
\hline July & 23 & 16 & 30 & 64 & 48 & 80 \\
\hline August & 24 & 17 & 31 & 68 & 52 & 84 \\
\hline September & 12 & 9 & 23 & 74 & 65 & 82 \\
\hline October & 11 & 5 & 17 & 76 & 68 & 84 \\
\hline November & 6 & 2 & 10 & 77 & 70 & 83 \\
\hline December & 3 & -1 & 5 & 79 & 72 & 85 \\
\hline
\end{tabular}

(1)Three years average. treatments was significant. According to Marić (1987), the tall oat-grass seed yield depends on the maturity stage and on the harvest method, and it can vary from 150 to $400 \mathrm{~kg} \mathrm{ha}^{-1}$. Trials with the diquat application at different maturity stages of bird's-foot trefoil seeds show that best results are achieved when $40 \%$ of pods with seeds are at the end of the dough stage (Petrovic et al., 1996). Clarke (1981) reported that the effect of different desiccants on wheat yield is not significant, but the effects of desiccants applied over different seed maturity stages are (Yenish \& Young, 2000).

However, the application of diquat in the earliest seed maturity stage resulted in significantly lower seed shedding in relation to the one observed with the application in the dough stage or in the control treatment (Table 2). This confirms the fact that the occurrence of generative stalks on the same plant is a pronounced phenomenon in tall oat-grass. In the same plant, seeds mature earlier in the upper part of the inflorescence and at the bottom of the spikelets, and then towards the periphery, resulting in uneven maturation and inevitable seed shedding (Stanisavljević et al., 2008). Petrović et al. (1996) showed that the diquat application in bird's-foot trefoil seed crop, at the stage in which $40 \%$ of pods and seeds in them were dark, at the end of the dough stage, contribute to seed shedding of only $5 \%$, while the application performed in latter stages resulted in seed shedding of over $30 \%$.

In each year of investigation, the application of desiccants in earlier maturity stages resulted in a significantly lower 1,000-seed weight, in comparison to the latter application (Table 3). The difference between control and this last treatment was not significant. The 1,000-seed weight was the greatest in the control treatment, but seed shedding was greater $(16.7 \%)$ in relation to the applications at the dough $(5.6 \%)$ and at the milk $(2.6 \%)$ stages. Therefore, the seed yield was significantly lower in the control treatment (Table 2). Studies done with wheat also showed that the 1,000 -seed weight is significantly lower in the milk stage than in the soft dough stage and in all succeeding maturity stages (Yenish \& Young, 2000).

Tall oat-grass seed germination in all combinations of treatments and years fulfilled the technological conditions and prescribed regulations of Southeastern European countries related to seed for trading and sowing. The difference in seed germination between the control treatment and the application at the dough 
stage was not significant (Table 3). Seeds obtained with the earlier desiccant application, on average, had significantly lower germination than seeds obtained in the other treatments. Similar results on desiccation effects at different stages of maturation on wheat seed germination were reported by Yenish \& Young (2000). However, desiccation applied in various maturity stages of alfalfa seeds did not show a significant effect on germination (May et al., 2003).

According to the Pearson's coefficient of correlation, the dependence between seed yield and the 1,000-seed weight was positive and significant, but rather low $(\mathrm{r}=0.327 ; \mathrm{p} \leq 0.05)$, while the association between yield and final germination was also positive but not significant $(r=0.151)$. However, the observed relationship between 1,000-seed weight and germination was positive and high $(\mathrm{r}=0.688 ; \mathrm{p} \leq 0.01)$. This high correlation was also observed in several grass species within a meadow community ( $\mathrm{Wu} \&$ $\mathrm{Du}, 2007)$. Increases in 1,000-seed weight and in the other yield components result in higher yields in the conventional seed production and, thereby, in a better financial result (Mirić et al., 2007).

The seed dormancy period depends on species genetic and physiological potentials (Simpson, 1990). Moreover, it depends on the storage conditions and on its interactions with environmental factors during seed storage (Merritt et al., 2003). The longer is the seed storage period, the faster are the germination losses, with pronounced differences among species (Walters et al., 2005; Nascimento et al., 2006). The low moisture content in combination with low storage temperatures maintain seed germination a longer period (Marić, 1987). In the present work, the temperature and relative air humidity varied according to the environmental conditions during seed maturing and aging in the storage (Table 1). However, these values represent common conditions of seed conservation in storages in the continental part of Southeastern Europe.

As expected, the lowest germination was observed immediately after harvest in partially dried seeds $(57 \%)$, with the greatest (31\%) seed dormancy (Table 4). A significant increase in germination occurred on the $60^{\text {th }} \mathrm{DAH}$ (from 57 to $62 \%$ ). At the time of autumn sowing (September), or approximately 90 to $120 \mathrm{DAH}$, seed germination amounted to $63-65 \%$, which does not satisfy the requirements of seed for trading in the majority of Southeastern Europe countries (minimum germination has to be $70 \%$ ). The greatest increase in germination was recorded between 120 and $150 \mathrm{DAH}$ (from 65 to $75 \%$ ), when seed reached the threshold of $70 \%$ germination. However, in case of tall oat-grass sown and germinated under natural conditions, winter-killing turns impossible the sowing near after $120 \mathrm{DAH}$ (October and further on). Germination significantly increased up to $180 \mathrm{DAH}$ (83\%), following a seed dormancy decrease to the minimum. Maximum germination was recorded

Table 2. Desiccation effects on seed yield and seed shedding of tall oat-grass ${ }^{(1)}$.

\begin{tabular}{|c|c|c|c|c|c|c|c|c|c|c|}
\hline \multirow[t]{2}{*}{ Treatment } & \multicolumn{3}{|c|}{ Seed yield $\left(\mathrm{kg} \mathrm{ha}^{-1}\right)$} & \multirow[t]{2}{*}{ Average } & \multirow[t]{2}{*}{$\mathrm{CV}(\%)$} & \multicolumn{3}{|c|}{ Shed seed $(\%)$} & \multirow[t]{2}{*}{ Average } & \multirow[t]{2}{*}{ CV (\%) } \\
\hline & 2007 & 2008 & 2009 & & & 2007 & 2008 & 2009 & & \\
\hline A & $412.6 b$ & $518.6 b$ & $448.3 b$ & $459.8 b$ & 11.7 & $2.8 \mathrm{c}$ & $1.9 \mathrm{c}$ & $3.1 \mathrm{c}$ & $2.6 \mathrm{c}$ & 24.0 \\
\hline B & $475.3 \mathrm{a}$ & $577.3 \mathrm{a}$ & $489.6 \mathrm{a}$ & $514.1 \mathrm{a}$ & 10.7 & $5.9 b$ & $4.8 \mathrm{~b}$ & $6.1 b$ & $5.6 \mathrm{~b}$ & 12.5 \\
\hline $\mathrm{C}$ & $397.9 \mathrm{~b}$ & $497.3 b$ & $401.3 \mathrm{~b}$ & $432.2 \mathrm{c}$ & 13.1 & $15.9 \mathrm{a}$ & $15.3 \mathrm{a}$ & $18.9 \mathrm{a}$ & $16.7 \mathrm{a}$ & 11.5 \\
\hline Average & 428.6 & 531.1 & 446.4 & 468.7 & 11.7 & 8.2 & 7.3 & 9.4 & 8.3 & 12.7 \\
\hline
\end{tabular}

${ }^{(1)}$ Means followed by equal letters, in the columns, do not differ by LSD test, at $5 \%$ probability.

Table 3. Desiccation effects on 1,000-seed weight and seed germination of tall oat-grass ${ }^{(1)}$.

\begin{tabular}{|c|c|c|c|c|c|c|c|c|c|c|}
\hline \multirow[t]{2}{*}{ Treatment } & \multicolumn{3}{|c|}{ 1,000-seed weight $(\mathrm{g})$} & \multirow[t]{2}{*}{ Average } & \multirow[t]{2}{*}{ CV $(\%)$} & \multicolumn{3}{|c|}{ Seed germination $(\%)$} & \multirow[t]{2}{*}{ Average } & \multirow[t]{2}{*}{ CV $(\%)$} \\
\hline & 2007 & 2008 & 2009 & & & 2007 & 2008 & 2009 & & \\
\hline A & $2.8 \mathrm{~b}$ & $3.1 \mathrm{~b}$ & $2.9 \mathrm{~b}$ & $2.9 \mathrm{~b}$ & 5.2 & $85.6 b$ & $82.3 b$ & $86.7 b$ & $84.7 b$ & 2.7 \\
\hline B & $3.3 \mathrm{a}$ & $3.4 \mathrm{a}$ & $3.3 \mathrm{a}$ & $3.3 \mathrm{a}$ & 1.7 & $89.8 \mathrm{a}$ & $88.6 \mathrm{a}$ & $88.9 \mathrm{a}$ & $89.1 \mathrm{a}$ & 0.7 \\
\hline $\mathrm{C}$ & $3.4 \mathrm{a}$ & $3.5 \mathrm{a}$ & $3.4 \mathrm{a}$ & $3.4 \mathrm{a}$ & 1.7 & $90.6 \mathrm{a}$ & $89.1 \mathrm{a}$ & $90.1 \mathrm{a}$ & $89.9 \mathrm{a}$ & 0.8 \\
\hline Average & 3.2 & 3.3 & 3.1 & 3.2 & 3.1 & 88.7 & 86.7 & 88.6 & 87.9 & 1.3 \\
\hline
\end{tabular}

${ }^{(1)}$ Means followed by equal letters, in the columns, do not differ by LSD test, at 5\% probability. 
at $210 \mathrm{DAH}$, but it was similar to those on 180 and 240 DAH. During this period, the length of roots and shoots, as well as seedling weights, reach their peak values, significantly higher than the ones observed immediately after harvest. This indicates that spring, i.e. March, is the best period for tall oat-grass sowing in the continental part of Southeastern Europe, when germination and seedling quality parameters have their maximum values. In addition, the risk of winter-killing of emerged seedlings ceases in this period.

During seed aging, starting from the $240^{\text {th }} \mathrm{DAH}$, a significant reduction in seed germination was recorded after every 90 days (Table 5). Seed germination was satisfactory up to the $420^{\text {th }} \mathrm{DAH}(75 \%)$, when autumn sowing (September) of forage grasses is optimal in this region (Miladinović et al., 2001). A significant reduction in the growth of the embryonic shoot and

Table 4. Changes in germination and seedling quality of tall oat-grass during post-harvest maturing, after desiccation with diquat ${ }^{(1)}$.

\begin{tabular}{|c|c|c|c|c|c|}
\hline \multirow{2}{*}{$\begin{array}{l}\text { Days after } \\
\text { harvest }\end{array}$} & \multirow{2}{*}{$\begin{array}{c}\text { Total } \\
\text { germination } \\
(\%)\end{array}$} & \multirow{2}{*}{$\begin{array}{c}\text { Dormant } \\
\text { seed } \\
(\%)\end{array}$} & \multicolumn{3}{|c|}{ Seedling quality } \\
\hline & & & $\begin{array}{l}\text { Shoot } \\
(\mathrm{cm})\end{array}$ & $\begin{array}{l}\text { Root } \\
(\mathrm{cm})\end{array}$ & $\begin{array}{c}\text { Fresh weight } \\
(\mathrm{mg})\end{array}$ \\
\hline 0 & $57 \mathrm{a}$ & $31 \mathrm{a}$ & $8.25 \mathrm{a}$ & $4.18 \mathrm{a}$ & $12.57 \mathrm{a}$ \\
\hline 30 & $59 \mathrm{ab}$ & $28 \mathrm{~b}$ & $8.28 \mathrm{ab}$ & $4.20 \mathrm{a}$ & $12.69 \mathrm{ab}$ \\
\hline 60 & $62 \mathrm{bc}$ & $24 \mathrm{c}$ & $8.32 \mathrm{ab}$ & $4.22 \mathrm{a}$ & $12.79 \mathrm{ab}$ \\
\hline 90 & $63 c$ & $20 \mathrm{~d}$ & $8.36 \mathrm{ab}$ & $4.24 \mathrm{a}$ & $12.81 \mathrm{ab}$ \\
\hline 120 & $65 \mathrm{c}$ & $14 \mathrm{e}$ & $8.39 \mathrm{ab}$ & $4.25 \mathrm{a}$ & $12.90 \mathrm{ab}$ \\
\hline 150 & $75 d$ & $11 \mathrm{f}$ & $8.48 \mathrm{ab}$ & $4.28 \mathrm{a}$ & $12.93 \mathrm{ab}$ \\
\hline 180 & $83 \mathrm{e}$ & $2 \mathrm{~g}$ & $8.50 \mathrm{ab}$ & $4.28 \mathrm{a}$ & $12.99 \mathrm{ab}$ \\
\hline 210 & $84 \mathrm{e}$ & $1 \mathrm{~g}$ & $8.66 \mathrm{~b}$ & $4.37 \mathrm{a}$ & $13.14 b$ \\
\hline 240 & $83 \mathrm{e}$ & $1 \mathrm{~g}$ & $8.64 \mathrm{~b}$ & $4.36 \mathrm{a}$ & $13.01 \mathrm{~b}$ \\
\hline CV (\%) & 15.8 & 80.2 & 3.6 & 1.5 & 1.4 \\
\hline
\end{tabular}

${ }^{(1)}$ Means followed by equal letters, in the columns, do not differ by LSD test, at $5 \%$ probability.

Table 5. Changes in germination and seedling quality of tall oat-grass during seed aging after desiccation with diquat ${ }^{(1)}$.

\begin{tabular}{|c|c|c|c|c|}
\hline \multirow{2}{*}{$\begin{array}{l}\text { Days after } \\
\text { harvest }\end{array}$} & \multirow{2}{*}{$\begin{array}{c}\text { Total germination } \\
(\%)\end{array}$} & \multicolumn{3}{|c|}{ Seedling quality } \\
\hline & & $\begin{array}{l}\text { Shoot } \\
(\mathrm{cm})\end{array}$ & $\begin{array}{l}\text { Root } \\
(\mathrm{cm})\end{array}$ & $\begin{array}{l}\text { Fresh weight } \\
(\mathrm{mg})\end{array}$ \\
\hline 240 & $83 a$ & $8.64 a$ & $4.36 \mathrm{a}$ & $13.01 \mathrm{a}$ \\
\hline 330 & $79 b$ & $8.39 \mathrm{~b}$ & $4.25 \mathrm{ab}$ & $12.73 \mathrm{ab}$ \\
\hline 420 & $75 c$ & $8.37 \mathrm{~b}$ & $4.22 b$ & $12.69 \mathrm{~b}$ \\
\hline 510 & $69 d$ & $8.30 \mathrm{~b}$ & $4.21 \mathrm{~b}$ & $12.54 \mathrm{~b}$ \\
\hline 600 & $64 \mathrm{e}$ & $8.26 b$ & $4.16 b$ & $12.51 \mathrm{~b}$ \\
\hline 690 & $61 \mathrm{f}$ & $8.24 b$ & $4.13 b$ & $12.50 \mathrm{~b}$ \\
\hline CV (\%) & 12.0 & 1.7 & 1.9 & 1.5 \\
\hline
\end{tabular}

${ }^{(1)}$ Means followed by equal letters, in the columns, do not differ by LSD test, at $5 \%$ probability. radicle, and in seedling weight also occurred during seed aging. According to Ross \& Harper (1972), the faster initial growth of the embryonic shoot and radicle provides better chances in the competition with other species.

\section{Conclusions}

1. The application of diquat desiccant at the beginning of the seed dough maturity stage results in the highest yield and satisfactory seed quality of tall oat-grass.

2. In the continental part of Southeastern Europe, regarding germination and seedling growth, early spring (March) is the best sowing period for freshly harvested seeds of tall oat-grass; and in case of good storage conditions, tall oat-grass seeds can be used for sowing up to 14 months after harvest.

\section{Acknowledgement}

To the Ministry of Science and Technology of the Republic of Serbia, for financial support.

\section{References}

ADKINS, S.W.; BELLAIRS, S.M.; LOCH, D.S. Seed dormancy mechanisms in warm season grass species. Euphytica, v.126, p.13-20, 2002.

BEWLEY, J.D. Seed germination and dormancy. Plant Cell, v.9, p.1055-1066, 1997.

CLARKE, J.M. Effect of diquat, paraquat and glyphosate on preharvest drying of wheat. Canadian Journal of Plant Science, v.61, p.909-913, 1981.

INTERNATIONAL SEED TESTING ASSOCIATION. International rules for seed testing. Zurich: ISTA, 2008. 31p.

MARIĆ, M. Semenarstvo. Belgrade: University of Belgrade, 1987. 389p.

MAY, W.E.; LOEPPKY, H.A.; MURRELL, D.C.; MYHRE, C.D.; SOROKA, J.J. Preharvest glyphosate in alfalfa for seed production: effect on alfalfa seed yield and quality. Canadian Journal of Plant Science, v.83, p.189-197, 2003.

MERRITT, D.J.; SENARATNA T.; TOUCHELL, D.H.; DIXON, K.W.; SIVASITHAMPARAM, K. Seed ageing of four Western Australian species in relation to storage environment and seed antioxidant activity. Seed Science Research, v.13, p.155-165, 2003.

MILADINOVIĆ, M. Proizvodnja semena krmnih biljaka. Novi Sad: Institute of Field and Vegetable Crops, 2001. 390p. 
MIRIĆ, M.; SELAKOVIĆ, D.; JOVIN, P.; HOJKA, Z.; FILIPOVIĆ, M. Thousand-seed weight in the theory and practice. Plant Breeding and Seed Production, v.13, p.49-58, 2007.

MITIĆ, N. Pesticidi u poljoprivredi i šumarstvu u Srbiji. Belgrade: Plant Protection Society of Serbia, 2000. 993p.

NASCIMENTO, W.M.; PEREIRA, R.S.; FREITAS, R.A. de; BLUMER, L.; MUNIZ, M.F.B. Colheita e armazenamento de sementes de coentro. Pesquisa Agropecuária Brasileira, v.12, p.1793-1801, 2006.

PETROVIĆ, R.; MILIJIĆ, S.; MLADENOVIĆ, G. Novine u tehnologiji gajenja žutog zvezdana sorte Bokor za proizvodnju semena. In: YUGOSLAV FORAGE CROPS SYMPOSIUM WITH INTERNATIONAL PARTICIPATION, 8., 1996, Novi Sad. Proceedings. Novi Sad: Institute of Field and Vegetable Crops, 1996. p.265-272.

ROSS, M.A.; HARPER, J.L. Occupation of biological space during seedling establishment. Journal of Ecology, v.60, p.77-88, 1972.

SCOTTON, M.; PICCININ, L.; DAINESE, M.; SANCIN, F. Seed production of an Arrhenatherion elatioris hay-meadow in the Eastern Italian Alps. Grass and Forage Science, v.64, p.208-218, 2009.

SIMPSON, G.M. Seed dormancy in grasses. Cambridge: Cambridge University Press, 1990. 297p.

SOKOlOviĆ, D.; RADOVIĆ, J.; IGNJATOVIĆ, S. Study of morphological traits and yield of tall oatgrass population from Serbia. Grasslands Science in Europe, v.9, p.437-439, 2004.

STANISAVLJEVIĆ, R.; SOKOLOVIĆ, D.; MILENKOVIĆ, J.; TERZIĆ, D.; DJOKIĆ, D.; SIMIĆ, A. Quality changes of common cat's tail (Phleum pratense L.) and franch raygrass (Arrhenatherum elatius L.) during ripening and correlative dependance of their significant characteristics. Plant Breeding and Seed Production, v.14, p.17-22, 2008.

TOMIĆ, Z.; BIJELIĆ, Z.; KRNJAJA, V. Analysis of grassland associations of Stara Planina Mountain. Biotechnology in Animal Husbandry, v.25, p.451-464, 2009.

TOMIĆ, Z.; SOKOLOVIĆ, D.; LUGIĆ, Z.; RADOVIĆ, J.; NEŠIĆ, Z.; MARINKOV, G. New domestic cultivars of perennial grasses used as livestock production. Biotechnology in Animal Husbandry, v.23, p.81-88, 2007.

WALTERS, C.; WHEELER, L.M.; GROTENHUIS, J.M. Longevity of seeds stored in a genebank: species characteristics. Seed Science Research, v.15, p.1-20, 2005.

WU, G.; DU, G. Germination is related to seed mass in grasses (Poaceae) of the eastern Qinghai-Tibetan Plateau, China. Nordic Journal of Botany, v.25, p.361-365, 2007.

YENISH, J.P.; YOUNG, F.L. Effect of preharvest glyphosate application on seed and seedling quality of spring wheat (Triticum aestivum). Weed Technology, v.14, p.212-217, 2000.

Received on February 11, 2010 and accepted on October 8, 2010 